\title{
Carbonic anhydrase IX enhances tumor cell proliferation and tumor progression in osteosarcoma
}

This article was published in the following Dove Press journal: OncoTargets and Therapy

\author{
Kazuma Okuno',2 \\ Takao Matsubara' \\ Tomoki Nakamura' \\ Takahiro lino' \\ Takuya Kakimoto' \\ Kunihiro Asanuma' \\ Akihiko Matsumine ${ }^{1,3}$ \\ Akihiro Sudo' \\ 'Department of Orthopedic Surgery, \\ Mie University Graduate School of \\ Medicine, Tsu, Mie, Japan; ${ }^{2}$ Department \\ of Orthopedic Surgery, Ise Red Cross \\ Hospital, Ise, Japan; ${ }^{3}$ Department of \\ Orthopedic Surgery, Fukui University \\ Graduate School of Medicine, \\ Fukui, Japan
}

Purpose: We investigated the effect of carbonic anhydrase IX (CA IX) inhibitor under hypoxia and normoxia in SaOS2 human osteosarcoma cell line. We also evaluated the expression of CA IX in 27 patients diagnosed with osteosarcoma.

Materials and methods: CA IX expression in SaOS2 cells cultured under different oxygen tensions was analyzed by Western blotting. To evaluate the effect of CA IX inhibitor, MTS cell viability assay was performed after cells were treated with various concentrations of doxorubicin with or without a CA IX inhibitor. Finally, CA IX expression in patient-derived osteosarcoma samples was evaluated by immunohistochemistry.

Results: Treatment with CA IX inhibitor significantly suppressed cell proliferation and migration under hypoxic conditions. CA IX expression was observed in $81 \%$ of 27 patients. The 5 -year survival rates in patients with high and low stain scores were $43.8 \%$ and $81.8 \%$, respectively. Conclusion: CA IX inhibitors have the potential to suppress cell proliferation, migration, and chemoresistance.

Keywords: hypoxia, osteosarcoma, carbonic anhydrase IX, inhibitor

\section{Introduction}

Differences in the special and temporal distribution of oxygen generate variable microenvironmental conditions within the tumor. Most solid tumors tend to have a slightly acidic, hypoxic, and a more complex microenvironment compared to the normal tissue. ${ }^{1,2}$ This microenvironment may influence tumor cell growth dynamics. ${ }^{3-5}$

In a previous study, we reported that the complex tumor microenvironment conditions in osteosarcoma cells affect the expression of genes related to tumor proliferation, migration, invasion, metabolism, and viability in an additive manner. ${ }^{6}$ Hypoxia and acidity were the major factors that affected the expression of tumor survival-related genes. It has been shown that hypoxia suppresses apoptosis, increases metastatic potential, and enhances resistance to chemotherapy and radiation therapy, thus contributing to tumor progression and survival. ${ }^{7,8}$

Carbonic anhydrase IX (CA IX) is one of the transmembrane enzymes which is induced by hypoxia. ${ }^{9}$ Its expression is regulated by hypoxia-inducible factor (HIF)- $1 \alpha$. Several tumor cells express membrane-bound CA IX. Despite recognizing that the expression of HIF-1 $\alpha$ and CA IX in tumors correlate with poor patient survival, the role of CA IX in tumor growth, especially osteosarcoma, is not fully resolved.

According to a previous report, CA IX is overexpressed in a wide variety of solid tumors, but not in normal human tissues. ${ }^{10}$ The primary enzymatic function

\footnotetext{
Correspondence: Kazuma Okuno Department of Orthopedic Surgery, Mie University Graduate School of Medicine, Edobashi 2-174, Tsu-City, Mie 5|4-8507, Japan

$\mathrm{Tel}+8|5923| 5022$

Fax +8| $5923|52| \mid$

Email qsghp572@yahoo.co.jp
}

(c) (i) (5) 2018 0kuno et al. This work is published and licensed by Dove Medical Press Limited. The full terms of this license are available at https://www.dovepress.com/terms.php C. hereby accept the Terms. Non-commercial uses of the work are permitted without any further permission from Dove Medical Press Limited, provided the work is properly attributed. For permission for commercial use of this work, please see paragraphs 4.2 and 5 of our Terms (https://www.dovepress.com/terms.php). 
of CA IX is to catalyze the reversible hydration of carbon dioxide to bicarbonate and protons. CA IX also acts as a catalytic converter for the excretion of acids from cells. In addition to this role, CA IX contributes to cell proliferation, adhesion, and migration, which are essential for the metastatic progression of several cancers. ${ }^{3-5}$ However, the role of CA IX in osteosarcoma progression is unclear. In this study, we investigated the effect of CA IX under hypoxia and normoxia in human osteosarcoma cell line - SaOS2. Furthermore, we evaluated the expression of CA IX in 27 patients with osteosarcoma of the lower limb using biopsy tissue samples.

\section{Materials and methods \\ Cell culture and growth curves}

Human osteosarcoma cell line, SaOS2 (RCB0428; Riken BioResource Center Cell Bank, Tsukuba, Japan), was used for this study. SaOS2 cells were cultured in McCoy's 5A medium supplemented with $15 \%$ FBS. To analyze the effect of different microenvironmental oxygen conditions on cell growth, $\mathrm{SaOS} 2$ cells $\left(5.0 \times 10^{2} /\right.$ well $)$ were cultured under hypoxic $\left(1 \% \mathrm{O}_{2}\right)$ or normoxic $\left(21 \% \mathrm{O}_{2}\right)$ conditions at $37^{\circ} \mathrm{C}$ with $5 \% \mathrm{CO}_{2}$ and $95 \%$ humidity in 96-well tissue culture plates. A hypoxic incubator $\left(\mathrm{CPO}_{2}-2301\right.$; Hirasawa Works, Tokyo, Japan) was used for cell culture. Hypoxia was achieved by using nitrogen-flushed hypoxic chambers. The culture medium was changed once every 2 days. MTS assay using CellTiter $96^{\circledR}$ AQueous One Solution Cell Proliferation Assay (G3581; Promega Corporation, Fitchburg, WI, USA) was performed to assess tumor cell viability.

\section{Western blotting}

The expression of the CA IX protein was analyzed by Western blotting. SaOS2 cells were cultured under $1 \%$ or $21 \% \mathrm{O}_{2}$ for 48 hours. Proteins were extracted from homogenized cells and separated by SDS-PAGE. Samples were adjusted to the same protein concentration before loading. Proteins were blotted on to a polyvinylidene difluoride membrane (EMD Millipore, Billerica, MA, USA) and incubated with primary mouse monoclonal anti-CA IX (M75; BioScience, Bratislava, Slovakia) antibody (1:500 in 5\% skim milk with Tris-buffered saline [pH 8.3]) for 12 hours at $4^{\circ} \mathrm{C}$. The membrane was then washed five times and incubated for 1 hour with anti-mouse IgG (Bio-Rad Laboratories Inc., Hercules, CA, USA; 1:2,000 in 1\% BSA in PBS). After washing, the bands were visualized using the enhanced chemiluminescence Western blotting detection system (GE Healthcare UK
Ltd, Little Chalfont, UK) and imaged using an ImageQuant LAS-4000 (Fujifilm, Tokyo, Japan). ${ }^{11,12}$

\section{The effect of inhibiting CA IX on cell proliferation}

SaOS 2 cells $\left(5.0 \times 10^{2} /\right.$ well) were cultured in medium supplemented with $15 \%$ FBS under $1 \%$ or $21 \% \mathrm{O}_{2}$ in 96 -well tissue culture plates. After 96 hours, the cells were treated with 10 MM 215900 (Calbiochem; EMD Millipore), a CA IX inhibitor. Cell viability was assayed 96 hours after treatment by MTS method.

\section{Effect of combined CA IX inhibitor - doxorubicin treatment}

$\mathrm{SaOS} 2$ cells $\left(5.0 \times 10^{2} /\right.$ well $)$ were cultured under $1 \%$ or $21 \%$ $\mathrm{O}_{2}$ in 96-well tissue culture plates. After 96 hours, the cells were treated with various concentrations $(0.01,0.1,1$, or $10 \mu \mathrm{M}$ ) of doxorubicin with or without $10 \mu \mathrm{M} 215900$ for 24 hours. After an additional 96 hours, cell viability was assayed by the MTS method.

\section{Cell migration assay}

Transwell chambers containing a polycarbonate membrane (Falcon ${ }^{\circledR}$ Cell culture Inserts; $8 \mu \mathrm{m}$ pore size; 24 -well plate) were used for the migration assay. SaOS2 cells $\left(5.0 \times 10^{2} /\right.$ well $)$ were cultured under $1 \%$ or $21 \% \mathrm{O}_{2}$ in 96 -well tissue culture plates for 7 days. The cells were then seeded into the upper chamber of the transwell chamber and incubated for 24 hours with or without $10 \mu \mathrm{M} 215900$. The cells that migrated across the membrane were quantified following the manufacturer's protocol (Falcon Cell culture).

\section{Expression of the CA IX protein in patients with osteosarcoma}

This study was approved by the institutional review board of Mie University Hospital, and written informed consent was obtained from all patients. We also acquired a written informed consent from a parent or a legal guardian for patients younger than 18 years. Twenty-seven patients (13 males and 14 females) with osteosarcoma of the lower limb were recruited. The mean age was 33 years (range, 5-81 years). Tumor sites were femur in 23 patients and tibia in four patients. The mean tumor size was $10 \mathrm{~cm}$ (range, 4-22 cm). Tissue samples were obtained before the initial treatment. The tumors were surgically resected in all patients except one who received chemotherapy alone. Adjuvant chemotherapy using doxorubicin, cisplatin, and methotrexate with or without ifosfamide was administered 
to 24 patients. The mean follow-up after initial treatment was 76 months (range, 3-206 months). Tissue samples were fixed in $10 \%$ buffered formalin solution and embedded in paraffin 24 hours later. Sections from two separate tumor areas were immunostained for CA IX (M75; mouse monoclonal antibody; BioScience). The expression of CA IX was evaluated microscopically. We excluded necrotic areas from the evaluation. The expression of CA IX was assessed by two parameters - the stained nuclear area of tumor cells ( $0-3$ points) and the intensity of staining ( $0-3$ points) according to the previous study. ${ }^{13}$ The maximum score was 6 , which reflects very high expression. We defined a score of 3 or higher as high expression.

\section{Statistical analyses}

All in vitro experiments were carried out in triplicates. A non-parametric ANOVA test (Mann-Whitney test) was used to compare differences between two groups. Overall survival was defined as the time from initial treatment to the date of death or final follow-up. The log-rank test was used for the analysis of prognostic factors. $P$-values are indicated in the figures. $P$-value $<0.05$ was considered statistically significant. Analyses were performed using SPSS statistical software (IBM Corporation, Armonk, NY, USA).

\section{Results \\ Expression of CA IX and effect of CA \\ IX inhibitor under different oxygen concentrations in SaOS2 cells}

Growth curves of SaOS2 cells in $1 \%$ and $21 \%$ oxygen are shown in Figure 1A. There was no difference in cell growth between these two oxygen concentrations. Western blotting showed that CA IX expression was higher under hypoxic conditions (Figure 1B). The proliferation rate of SaOS2 cells in each oxygen concentrations with or without the CA IX inhibitor is shown in Figure 1C. The CA IX inhibitor, $215900(10 \mu \mathrm{M})$, significantly suppressed cell proliferation under the hypoxic condition.

\section{Chemoresistance in hypoxia and the effect of the CA IX inhibitor}

Treatment with doxorubicin significantly decreased cell viability in $\mathrm{SaOS} 2$ cells cultured in normoxic and hypoxic conditions in a dose-dependent manner (Figure 2). The combined treatment with $0.1 \mu \mathrm{M}$ doxorubicin and $10 \mu \mathrm{M}$ 215900 significantly decreased the cell viability compared to doxorubicin only treatment under hypoxia (Figure 3). The combined treatment did not affect the cell viability significantly under normoxia.
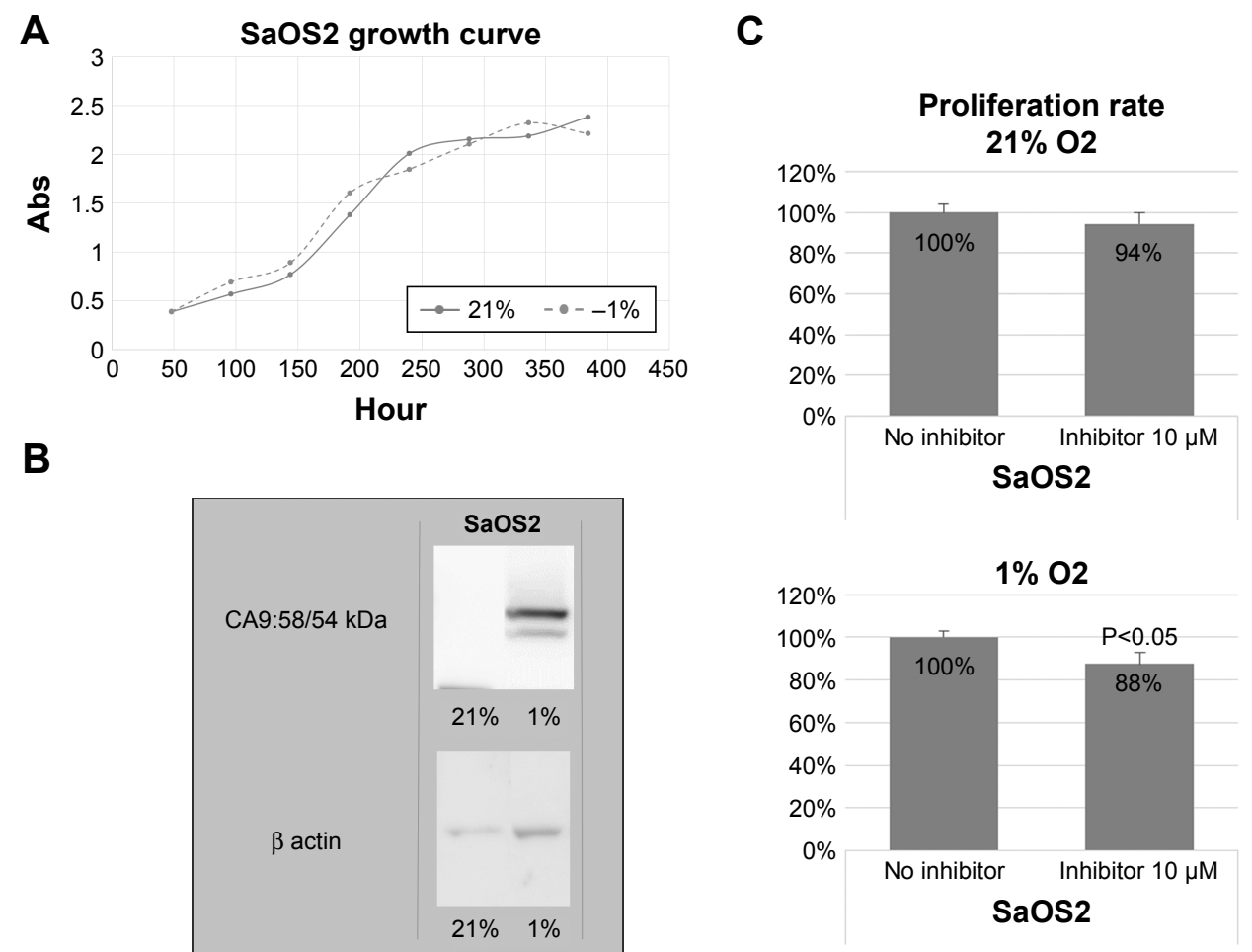

Figure I (A) SaOS2 growth curves under different oxygen concentrations. (B) CA IX expression in SaOS2 cells grown under different oxygen tensions. (C) SaOS2 proliferation under different oxygen tensions with or without CA IX inhibitor. Abbreviation: CA IX, carbonic anhydrase IX. 


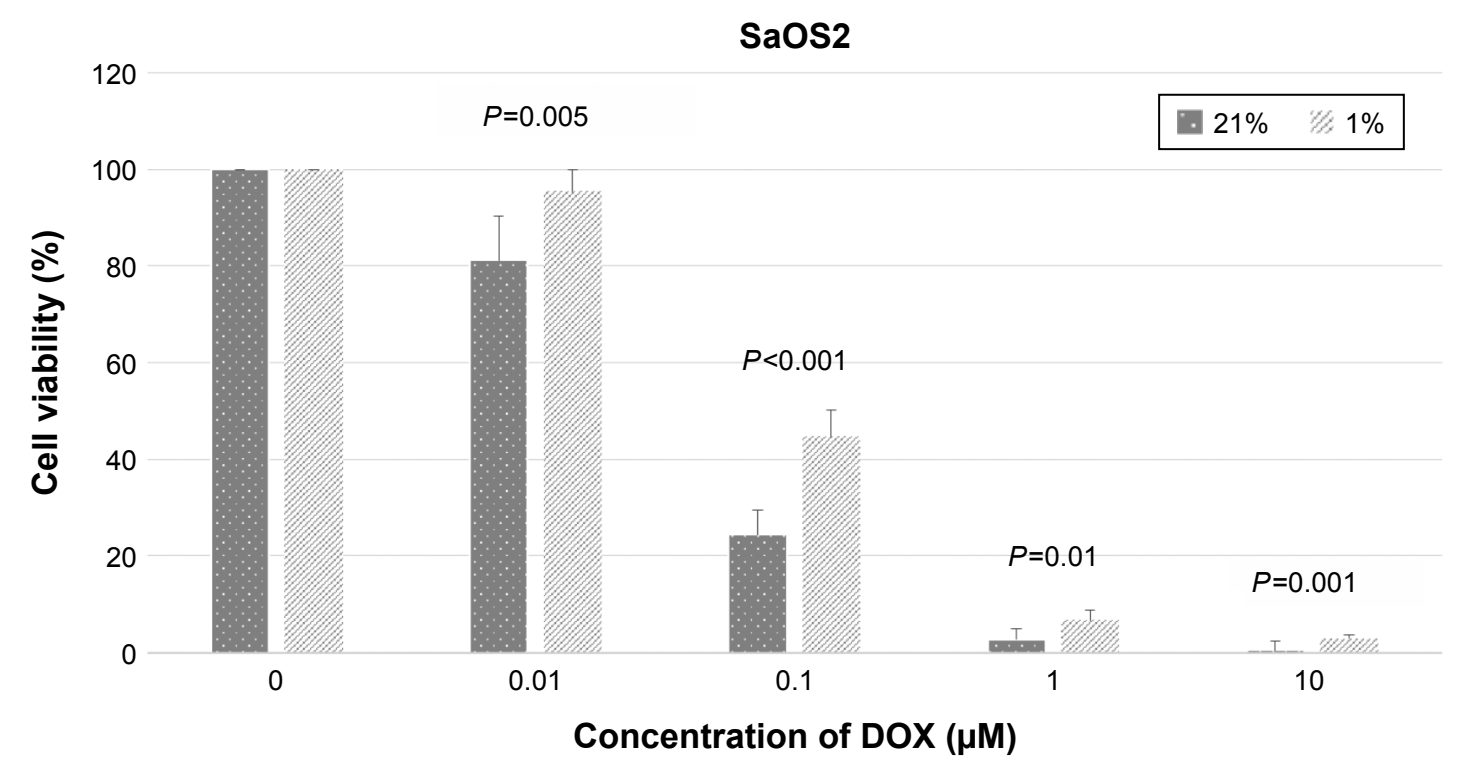

Figure 2 Effect of doxorubicin treatment on cell viability under normoxia and hypoxia. Abbreviation: DOX, doxorubicin.

\section{Effect of the CA IX inhibitor on cell migration}

In the Transwell chamber assay, the number of cells migrating through the membrane was significantly higher under hypoxic than normoxic conditions. Although a similar trend was observed with CA IX inhibitor treatment, a treatmentinduced reduction in the number of migrating cells was observed under hypoxia (Figure 4).

\section{Expression of CA IX in patients with osteosarcoma and the clinical outcome}

Of the 27 patients recruited for the study, CA IX protein expression was observed in 22 (81\%) patients (Figure 5). The mean expression score was 2.7 (range, 0-5). A high stain score was observed in 16 patients, while a low or no stain score was seen in 11 patients. Patients with a high stain score had a marginally poor prognosis for overall survival

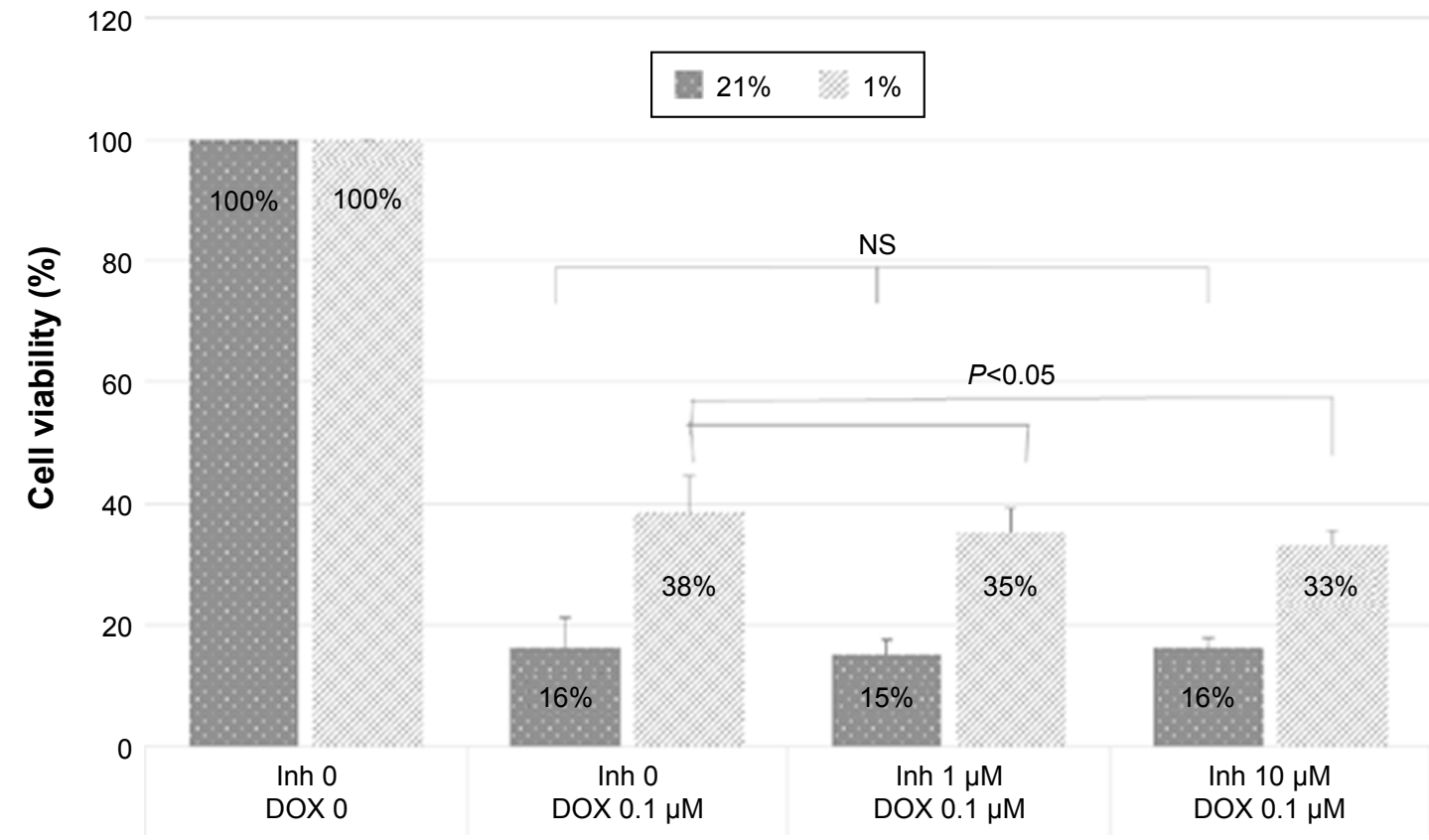

Figure 3 Effect of the combined CA IX inhibitor-doxorubicin treatment on cell viability. Abbreviations: CA IX, carbonic anhydrase IX; DOX, doxorubicin; NS, not significant. 

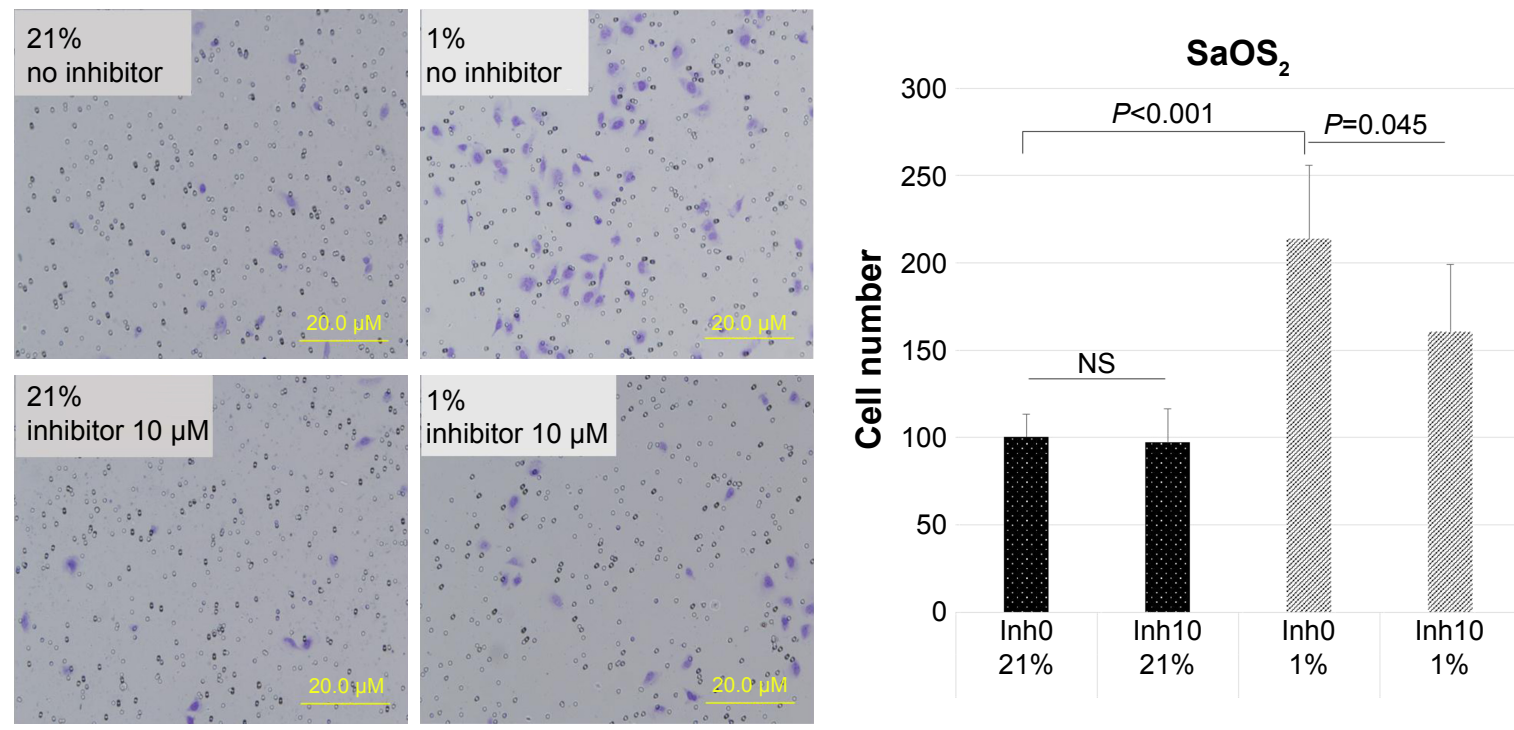

Figure 4 Transwell migration assay. SaOS2 cells stained with Diff-Quick solution (left), and the number of migrating cells under different oxygen concentrations with or without $10 \mu \mathrm{M}$ inhibitor (right).

Abbreviation: NS, not significant.

compared to those with a low or no stain score. The 5-year survival rates in patients with high and low stain scores were $43.8 \%$ (95\% CI, 19.4-68.1) and 81.8\% (95\% CI, 59-100), respectively $(P=0.058$; Figure 6$)$. Age $(P=0.03)$ and metastasis at initial presentation $(P=0.02)$ were also related to prognosis (Table 1).

\section{Discussion}

Osteosarcoma is the most common primary malignant bone tumor in children and young adults. Surgery and neoadjuvant and adjuvant chemotherapy are the standard initial treatments for osteosarcoma. However, treatment options for recurrent or advanced osteosarcoma are limited. New prognostic factors and markers for refining risk group allocation and improving treatment outcome are therefore urgently needed.

CAs are a large family of zinc metalloenzymes that catalyze the reversible hydration of carbon dioxide. CA IX is a transmembrane protein and a tumor-associated CA isoenzyme. Studies have reported that CA IX is expressed in several cancers, including renal cell, ${ }^{14}$ colorectal, ${ }^{15}$ nonsmall cell lung,,${ }^{16,17}$ cervical, ${ }^{18}$ bladder ${ }^{19}$ nasopharyngeal, ${ }^{20}$ breast, ${ }^{21}$ and soft tissue sarcoma, ${ }^{22}$ although it is absent in most normal human tissues. ${ }^{23}$

In this study, CA IX expression was observed in $81 \%$ of the patients with osteosarcoma. Furthermore, patients with a high immunohistochemical stain score had a marginally poor prognosis, compared to those with a low stain score. Although a small number of patients were evaluated in this study, we believe that additional research may validate our results.

Only a few reports are available on the CA IX expression in osteosarcoma cells. ${ }^{24}$ In the present study, CA IX was expressed under hypoxic conditions in human osteosarcoma cell line SaOS2. Furthermore, a CA IX inhibitor significantly
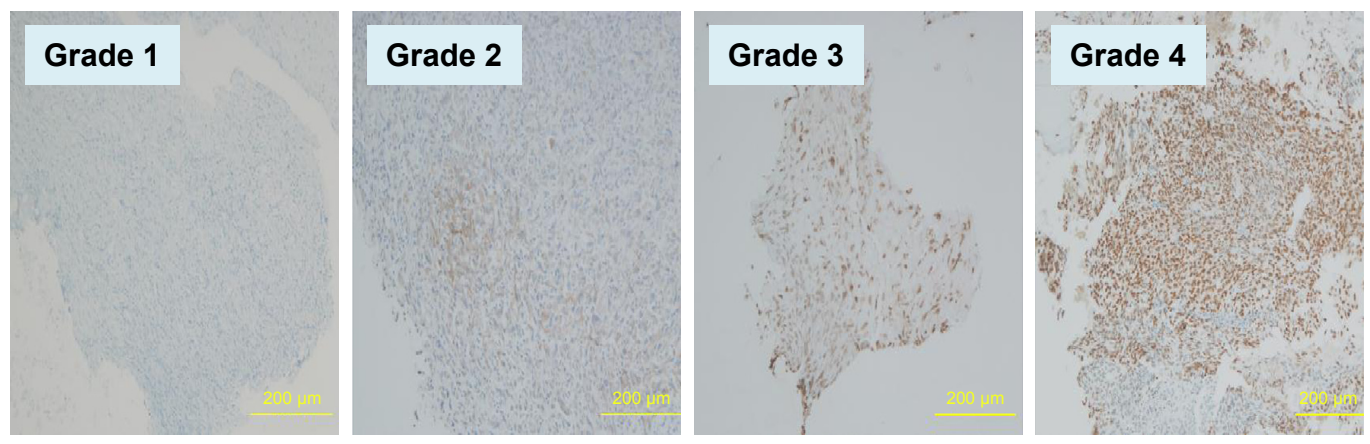

Figure 5 Expression of CA IX in patient osteosarcoma tissue samples. Abbreviation: CA IX, carbonic anhydrase IX. 


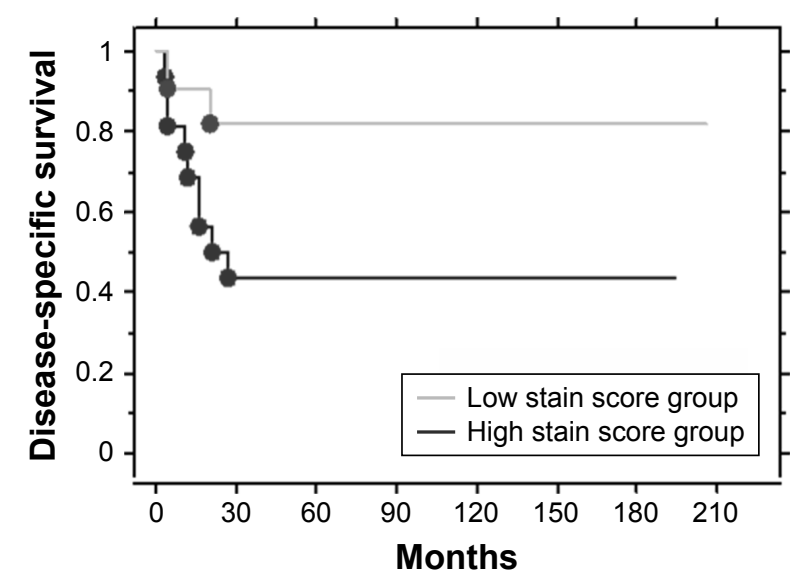

Figure 6 Kaplan-Meier analysis of overall survival in patients diagnosed with osteosarcoma.

suppressed the growth of these cells under hypoxic conditions. A previous report showed that selective inhibition of CA IX suppressed cell survival by inducing apoptosis. ${ }^{3} \mathrm{CA}$ IX mediates the transport of intracellular $\mathrm{H}^{+}$to the extracellular space to maintain homeostasis in tumor cells. ${ }^{25,26} \mathrm{CA}$ IX is also reported to have a major role in regulating $\mathrm{H}^{+}$flux, and blocking CA IX is reported to increase cell death. ${ }^{27}$

Hypoxia may not be the only mechanism by which CA expression is activated in tumors. Signaling through the EGF pathway by phosphorylation of a cytoplasmic tyrosine residue of CA IX may either activate CA IX or enhance its expression by increasing the translation of HIF- $1 \alpha{ }^{28}$ Thus, CA IX may be regulated through several pathways and may affect cell viability and invasiveness.

Table I The prognostic factor for survival

\begin{tabular}{|l|l|l|l|}
\hline Variables & n & $\begin{array}{l}\text { 5-year OS (\%) } \\
(95 \% ~ C l)\end{array}$ & P-value \\
\hline Age (years) & 15 & $40(15.2-64.8)$ & \\
\hline$>20$ & 12 & $83.3(62.2-100)$ & 0.03 \\
\hline$<20$ & 13 & $61.5(35.1-88)$ & \\
\hline Sex & 14 & $57.1(31.2-83.1)$ & 0.86 \\
\hline Male & \multicolumn{5}{|l|}{} \\
\hline Female & 17 & $52.9(29.2-76.7)$ & \\
\hline Size (cm) & 10 & $70(41.6-98.4)$ & 0.39 \\
\hline$>8$ & 4 & $25(0-67.4)$ & \\
\hline$<8$ & 23 & $65.2(45.8-84.7)$ & 0.02 \\
\hline Metastasis at presentation & & \\
\hline Yes & 16 & $43.8(19.4-68.1)$ & 0.058 \\
\hline No & 11 & $81.8(59-100)$ & \\
\hline Stain score &
\end{tabular}

Abbreviation: OS, overall survival.
In recent years, a hypoxic environment has been considered to be related to chemoresistance. Acidification of the solid tumor environment may reduce the activity of weakly basic anticancer drugs and lead to chemoresistance. ${ }^{29,30}$ In the present study, the toxicity of doxorubicin was reduced under hypoxic conditions.

Most anticancer agents enter into cells by either active transport or passive diffusion and undergo further metabolism. ${ }^{31}$ Extracellular and intracellular $\mathrm{pH}$ affect the transport of the drugs into the cells affecting their cytotoxic activities. Weakly ionized drugs enter the cell by passive diffusion in a non-ionized form. Such drugs tend to be preferentially distributed across compartments where their ionized form dominates across cell membranes. ${ }^{31}$ In addition, the variation in $\mathrm{pH}$ affects the toxicity of several drugs through mechanisms that are independent of ionization-dependent diffusion through the cell membrane. ${ }^{31}$

The suppression of tumor growth induced by the weak base doxorubicin is enhanced by increasing the extracellular $\mathrm{pH}$ of tumors after chronic ingestion of a sodium bicarbonate solution. ${ }^{30}$ We used doxorubicin in this study as it is a key chemotherapy agent in the treatment of osteosarcoma. CA IX inhibitors have been previously shown to elicit synergistic effects when used in combination with other chemotherapeutic agents in animal models. ${ }^{32}$ Targeting CA IX using specific inhibitors or antibodies should enhance the action of weakly basic drugs and also reduces the acquisition of metastatic phenotypes by controlling the $\mathrm{pH}$ imbalance in tumor cells. ${ }^{33}$ The results of our study demonstrated that the combined use of a CA IX inhibitor and doxorubicin enhanced the cytocidal effects of doxorubicin.

In the current study, treatment with a CA IX inhibitor suppressed tumor migration under hypoxic conditions in vitro. This might be because of the suppression in $\mathrm{CA}$ IX-mediated decrease in E-cadherin- $\beta$-catenin interactions. ${ }^{34}$ 215900 inhibitor is described as a CA inhibitor that is selective for both human CA IX and CA XII. A recent study had demonstrated that CA XII inhibitor abrogates chemoresistance and significantly reduces lung metastases in in vivo breast cancer model. ${ }^{35}$ A similar CA XII inhibition by 215900 might have contributed to the inhibitory effects observed in this study. Further studies are required to characterize 215900-mediated CA XII inhibition and to elucidate the role of CA XII in human osteosarcoma.

\section{Conclusion}

Osteosarcoma patients with a high staining score of CA IX had a poor prognosis. CA IX expression may be used as a potential biomarker high-risk osteosarcoma. This would 
enable the administration of personalized treatment strategy for high-risk patients, improving the overall treatment outcome in osteosarcoma. Treatment with a CA IX inhibitor suppressed cell proliferation, migration, and chemoresistance. Thus, CA IX inhibitors may be beneficial as combination drugs in the treatment of osteosarcoma. However, further research is necessary to explore the use of CA IX as a biomarker and to evaluate the therapeutic efficacy of CA IX inhibitors in the clinic.

\section{Disclosure}

The authors report no conflicts of interest in this work.

\section{References}

1. Mcdonald PC, Winum JY, Supuran CT, Dedhar S. Recent developments in targeting carbonic anhydrase ix for cancer therapeutics. Oncotarget. 2002;3(1):84-97.

2. Parks SK, Chiche J, Pouyssegur J. pH control mechanisms of tumor survival and growth. J Cell Physiol. 2011;226(2):299-308.

3. Cianchi F, Vinci MC, Supuran CT, et al. Selective inhibition of carbonic anhydrase IX decreases cell proliferation and induces ceramide-mediated apoptosis in human cancer cells. J Pharmacol Exp Ther. 2010;334(3): 710-719.

4. Shin HJ, Rho SB, Jung DC, Han IO, Oh ES, Kim JY. Carbonic anhydrase IX (CA9) modulates tumor-associated cell migration and invasion. $J$ Cell Sci. 2011;124(Pt 7):1077-1087.

5. Csaderova L, Debreova M, Radvak P, et al. The effect of carbonic anhydrase IX on focal contacts during cell spreading and migration. Front Physiol. 2013;4:271.

6. Matsubara T, Diresta GR, Kakunaga S, Li D, Healey JH. Additive Influence of Extracellular pH, Oxygen Tension, and Pressure on Invasiveness and Survival of Human Osteosarcoma Cells. Front Oncol 2013;3:199.

7. Ilie M, Mazure NM, Hofman V, et al. High levels of carbonic anhydrase IX in tumour tissue and plasma are biomarkers of poor prognostic in patients with non-small cell lung cancer. Br J Cancer. 2010; 102(11):1627-1635.

8. Korkeila E, Talvinen K, Jaakkola PM, et al. Expression of carbonic anhydrase IX suggests poor outcome in rectal cancer. Br J Cancer. 2009;100(6):874-880.

9. Swietach P, Vaughan-Jones RD, Harris AL. Regulation of tumor pH and the role of carbonic anhydrase 9. Cancer Metastasis Rev. 2007; 26(2):299-310.

10. Lou Y, Mcdonald PC, Oloumi A, et al. Targeting tumor hypoxia: suppression of breast tumor growth and metastasis by novel carbonic anhydrase IX inhibitors. Cancer Res. 2011;71(9):3364-3376.

11. Parkkila S, Rajaniemi H, Parkkila AK, et al. Carbonic anhydrase inhibitor suppresses invasion of renal cancer cells in vitro. Proc Natl Acad Sci U S A. 2000;97(5):2220-2224.

12. Nakazora S, Matsumine A, Iino $\mathrm{T}$, et al. The cleavage of $\mathrm{N}$-cadherin is essential for chondrocyte differentiation. Biochem Biophys Res Commun. 2010;400(4):493-499.

13. Shintani K, Matsumine A, Kusuzaki K, et al. Expression of hypoxiainducible factor (HIF)-1alpha as a biomarker of outcome in soft-tissue sarcomas. Virchows Arch. 2006;449(6):673-681.

14. Li G, Bilal I, Gentil-Perret A, et al. CA9 as a molecular marker for differential diagnosis of cystic renal tumors. Urol Oncol. 2012;30(4): 463-468.

15. Saarnio J, Parkkila S, Parkkila AK, et al. Immunohistochemical study of colorectal tumors for expression of a novel transmembrane carbonic anhydrase, MN/CA IX, with potential value as a marker of cell proliferation. Am J Pathol. 1998;153(1):279-285.
16. Giatromanolaki A, Koukourakis MI, Sivridis E, et al. Expression of hypoxia-inducible carbonic anhydrase- 9 relates to angiogenic pathways and independently to poor outcome in non-small cell lung cancer. Cancer Res. 2001;61(21):7992-7998.

17. Vermylen P, Roufosse C, Burny A, et al. Carbonic anhydrase IX antigen differentiates between preneoplastic malignant lesions in non-small cell lung carcinoma. Eur Respir J. 1999;14(4):806-811.

18. Olive PL, Aquino-Parsons C, Macphail SH, et al. Carbonic anhydrase 9 as an endogenous marker for hypoxic cells in cervical cancer. Cancer Res. 2001;61(24):8924-8929.

19. Turner KJ, Crew JP, Wykoff CC, et al. The hypoxia-inducible genes VEGF and CA9 are differentially regulated in superficial vs invasive bladder cancer. Br J Cancer. 2002;86(8):1276-1282.

20. Hui EP, Chan AT, Pezzella F, et al. Coexpression of hypoxia-inducible factors 1alpha and 2alpha, carbonic anhydrase IX, and vascular endothelial growth factor in nasopharyngeal carcinoma and relationship to survival. Clin Cancer Res. 2002;8(8):2595-2604.

21. Span PN, Bussink J, Manders P, Beex LV, Sweep CG. Carbonic anhydrase-9 expression levels and prognosis in human breast cancer: association with treatment outcome. Br J Cancer. 2003;89(2): 271-276.

22. Måseide K, Pintilie M, Kandel R, Hill RP. Can sparsely and heterogeneously expressed proteins be detected using tissue microarrays? A simulation study of the hypoxia marker carbonic anhydrase IX (CA IX) in human soft tissue sarcoma. Pathol Res Pract. 2008;204(3): $175-183$.

23. Wykoff CC, Beasley NJ, Watson PH, et al. Hypoxia-inducible expression of tumor-associated carbonic anhydrases. Cancer Res. 2000; 60(24):7075-7083.

24. Perut F, Carta F, Bonuccelli G, et al. Carbonic anhydrase IX inhibition is an effective strategy for osteosarcoma treatment. Expert Opin Ther Targets. 2015;19(12):1593-1605.

25. Cardone RA, Casavola V, Reshkin SJ. The role of disturbed $\mathrm{pH}$ dynamics and the $\mathrm{Na}+\mathrm{H}+$ exchanger in metastasis. Nat Rev Cancer. 2005;5(10):786-795.

26. Sedlakova O, Svastova E, Takacova M, Kopacek J, Pastorek J, Pastorekova S. Carbonic anhydrase IX, a hypoxia-induced catalytic component of the $\mathrm{pH}$ regulating machinery in tumors. Front Physiol. 2014;4:400.

27. Potter C, Harris AL. Hypoxia inducible carbonic anhydrase IX, marker of tumour hypoxia, survival pathway and therapy target. Cell Cycle. 2004;3(2):164-167.

28. Svastová E, Hulíková A, Rafajová M, et al. Hypoxia activates the capacity of tumor-associated carbonic anhydrase IX to acidify extracellular pH. FEBS Lett. 2004;577(3):439-445.

29. Vukovic V, Tannock IF. Influence of low $\mathrm{pH}$ on cytotoxicity of paclitaxel, mitoxantrone and topotecan. Br J Cancer. 1997;75(8):1167-1172.

30. Raghunand N, He X, van Sluis R, et al. Enhancement of chemotherapy by manipulation of tumour pH. Br J Cancer. 1999;80(7):1005-1011.

31. Stubbs M, Mcsheehy PM, Griffiths JR, Bashford CL. Causes and consequences of tumour acidity and implications for treatment. Mol Med Today. 2000;6(1):15-19.

32. Teicher BA, Liu SD, Liu JT, Holden SA, Herman TS. A carbonic anhydrase inhibitor as a potential modulator of cancer therapies. Anticancer Res. 1993;13(5A):1549-1556.

33. Thiry A, Dogné JM, Masereel B, Supuran CT. Targeting tumorassociated carbonic anhydrase IX in cancer therapy. Trends Pharmacol Sci. 2006;27(11):566-573.

34. Svastová E, Zilka N, Zat'ovicová M, et al. Carbonic anhydrase IX reduces E-cadherin-mediated adhesion of MDCK cells via interaction with beta-catenin. Exp Cell Res. 2003;290(2):332-345.

35. von Neubeck B, Gondi G, Riganti C, et al. An inhibitory antibody targeting carbonic anhydrase XII abrogates chemoresistance and significantly reduces lung metastases in an orthotopic breast cancer model in vivo. Int J Cancer. 2018;143(8):2065-2075. 


\section{Publish your work in this journal}

OncoTargets and Therapy is an international, peer-reviewed, open access journal focusing on the pathological basis of all cancers, potential targets for therapy and treatment protocols employed to improve the management of cancer patients. The journal also focuses on the impact of management programs and new therapeutic agents and protocols on

patient perspectives such as quality of life, adherence and satisfaction. The manuscript management system is completely online and includes a very quick and fair peer-review system, which is all easy to use. Visit http://www.dovepress.com/testimonials.php to read real quotes from published authors.

Submit your manuscript here: http://www.dovepress.com/oncotargets-and-therapy-journal 